\title{
Liquid Swine Manure Can Kill Verticillium dahliae Microsclerotia in Soil by Volatile Fatty Acid, Nitrous Acid, and Ammonia Toxicity
}

\author{
Kenneth L. Conn, Mario Tenuta, and George Lazarovits
}

First and third authors: Southern Crop Protection and Food Research Centre, Agriculture and Agri-Food Canada, 1391 Sandford Street, London, ON, Canada N5V 4T3; and second author: Department of Soil Science, University of Manitoba, Winnipeg, MB, Canada R3T 2N2. Accepted for publication 28 July 2004.

\begin{abstract}
Conn, K. L., Tenuta, M., and Lazarovits, G. 2005. Liquid swine manure can kill Verticillium dahliae microsclerotia in soil by volatile fatty acid, nitrous acid, and ammonia toxicity. Phytopathology 95:28-35.

In previous studies, liquid swine manure (LSM) was sometimes shown to reduce Verticillium wilt of potato caused by Verticillium dahliae. We also observed that microsclerotia of this fungus died within 1 day, or between 3 and 6 weeks, after addition of LSM to some acid soils and within 1 week in some alkaline soils. In this study, we demonstrated that a volatile fatty acid (VFA) mixture with an identical concentration of VFAs as that found in an effective LSM reduced germination in an acid soil $(\mathrm{pH}$ 5.1 ) to the same extent as the LSM after 1 day of exposure. Germination was reduced by 45,75 , and $90 \%$ in the 10,20 , and $40 \%$ ([wt/wt] soil moisture) treatments, respectively, with the latter being equivalent to an application of $80 \mathrm{hl} / \mathrm{ha}$. Addition to this acid soil of $19 \mathrm{LSMs}(30 \%$ [wt/wt] soil moisture) collected from different producers resulted in complete kill of microsclerotia with 12 manures. Effective manures had a total concentration of nonionized forms of VFAs in soil solution of $2.7 \mathrm{mM}$

or higher. In some acid soils ( $\mathrm{pH} 5.8$ ), addition of LSM (40\% [wt/wt] soil moisture) did not kill microsclerotia until 3 to 6 weeks later. Here, a reduction in viability of microsclerotia was attributed to the accumulation of $0.06 \mathrm{mM}$ nitrous acid in the soil solution at 4 weeks. When an LSM was added (40\% [wt/wt] soil moisture) to an alkaline soil ( $\mathrm{pH} 7.9)$ where VFAs are not toxic, microsclerotia germination was reduced by $80 \%$ after 1 week. Here the $\mathrm{pH}$ increased to 8.9 and the concentration of ammonia reached $30 \mathrm{mM}$ in the soil solution. An ammonium chloride solution having an equivalent concentration of ammonium as the manure was shown to have the same spectrum of toxicity as the manure in assays ranging from $\mathrm{pH} 7$ to 9 , both in solutions and above the solutions. At $\mathrm{pH} 9$, the concentration of ammonia reached $18 \mathrm{mM}$ and $100 \%$ mortality of microsclerotia occurred. Thus, in acid soils, LSM can kill microsclerotia of $V$. dahliae by VFA and/or nitrous acid toxicity and in alkaline soils by ammonia toxicity. In order to take advantage of these mechanisms for disease reduction, the manure chemical composition, rate of addition, and soil characteristics need to be determined for each instance of use.
\end{abstract}

A single application of liquid swine manure (LSM, $55 \mathrm{hl} / \mathrm{ha}$ ) to a potato field (site B) having an acid soil resulted in a 3-year reduction of Verticillium wilt, caused by the fungus Verticillium dahliae Kleb. (1). In subsequent investigations as to the basis for this disease control, we observed that $V$. dahliae microsclerotia died within 1 day or between 3 and 6 weeks after addition of LSM to some acid soils and within 1 week in some alkaline soils. LSM was not lethal to microsclerotia in neutral $\mathrm{pH}$ soils (2). Bioassays with LSM in solution indicated that volatile fatty acids (VFAs) in LSM might be responsible for the 1-day toxicity in acid soils (12). The major VFA component was acetic acid and represents about $60 \%$ of the active ingredient in LSMs that kill this pathogen (12). The other VFAs include propionic, $n$-butyric, isobutyric, $n$-valeric, isovaleric, and $n$-caproic acids. Only the nonionized forms of VFAs (e.g., acetic acid, not acetate) are toxic to $V$. dahliae microsclerotia (12) and other microorganisms $(5,6,18)$. The pKa of the VFAs in LSM ranges from 4.8 to 5.0. VFAs are fermentation products present in fecal material or generated during storage of swine manure under anaerobic conditions. They are rapidly oxidized by heterotrophic soil microorganisms within days of manure addition to soil $(4,9)$.

In several tests with LSM added to acid soils, we found no immediate reduction in germination of microsclerotia but kill was found at 3 to 6 weeks, which coincided with a decrease in soil $\mathrm{pH}$

Corresponding author: G. Lazarovits; E-mail address: lazarovitsg@ agr.gc.ca

DOI: 10.1094/PHYTO-95-0028

This article is in the public domain and not copyrightable. It may be freely reprinted with customary crediting of the source. The American Phytopathological Society, 2005. below 5. This could not be due to VFAs, but such toxicity had been previously found to result from the generation of nitrous acid after application of high nitrogen-containing products $(13,17)$. Release of ammonium from the degradation of these nitrogenous amendments by microorganisms was shown to cause a rise in soil $\mathrm{pH}$, which was then followed by a decline in soil $\mathrm{pH}$ when the ammonium was converted to nitrite. When the $\mathrm{pH}$ falls below 6, some of the nitrite is in the form of nitrous acid ( $\mathrm{pKa}$ of $\mathrm{HNO}_{2} / \mathrm{NO}_{2}^{-}$is 3.3). Nitrous acid was shown to be lethal to microsclerotia in acid soil after addition of nitrogenous amendments (13).

Toxicity of LSM to microsclerotia was occasionally observed when LSM was incorporated into alkaline soils where VFAs are not toxic. LSM contains considerable amounts of ammonium, making it a readily available source of nitrogen to crops. Ammonia has also been shown to be toxic to microsclerotia $(13,14)$. The ratio of ammonia to ammonium depends upon $\mathrm{pH}$. As $\mathrm{pH}$ increases, ammonium is converted to ammonia ( $\mathrm{pKa}$ of $\mathrm{NH}_{4}{ }^{+} / \mathrm{NH}_{3}$ is 9.3). LSM has not been previously considered as a high nitrogen-containing organic amendment.

The objective of this study was to determine if LSM can kill microsclerotia of $V$. dahliae in soil by multiple mechanisms. The possible toxicity due to VFAs, nitrous acid, and/or ammonia was investigated using a series of laboratory microcosm assays. Preliminary results of this study have been presented $(3,8)$.

\section{MATERIALS AND METHODS}

Manures. The LSMs used in this study were collected from lagoons at various swine operations in the Canadian provinces of 
Ontario and Prince Edward Island and were stored frozen until needed. LSM 96-01 was used as a positive control in all experiments carried out in this study. This manure was consistently lethal to microsclerotia when added to acid soils or solutions in all previous studies by our laboratory $(1,2,12)$. The concentration of VFAs (ionized plus nonionized forms) and ammonia plus ammonium in the manures was determined by ion exclusion and exchange chromatography (described below), respectively, and is shown in Table 1. The total VFA concentration ranged from 9.3 to $400 \mathrm{mM}$ and the ammonium plus ammonia concentration ranged from 96 to $500 \mathrm{mM}$. The $\mathrm{pH}$ values of the manures ranged from 7.0 to 8.6 and are shown in Table 1. VFAs are rapidly degraded in soil within days of addition of LSM to aerobic soil. We estimated the maximum concentration of associated VFAs in amended soil from the concentration in LSM, the LSM addition rate, and soil $\mathrm{pH}$ immediately after addition of LSM to soil.

Soils. Chemical and physical characteristics of the soils used in this study are detailed in Table 2 . Soil was collected from at least 10 locations within each site. The samples from each site were combined, brought back to the laboratory, and stored at $4^{\circ} \mathrm{C}$. Prior to use, soils were air-dried for 3 to 4 days to reduce their moisture content to allow addition of various amounts of water, LSM, or other solutions. Subsamples of air-dried soils were oven-dried for $24 \mathrm{~h}$ at $105^{\circ} \mathrm{C}$ to determine the volume of water remaining. This residual water content was taken into account when adjusting soil-manure or solution mixtures to specific moisture levels. Air- dried soils were stored at $4^{\circ} \mathrm{C}$ until the day prior to set up of an experiment when the quantity of soils needed for that particular experiment were placed at room temperature.

V. dahliae microsclerotia bioassay. A V. dahliae isolate (GL-1) obtained from an eggplant (Solanum melongena L. cv. Imperial Black Beauty) grown in $V$. dahliae-infested soil was reared on semisolid Czapek-Dox medium for 3 weeks in the dark at $24^{\circ} \mathrm{C}$. The culture was then poured through mesh screens to obtain microsclerotia between 76 and $106 \mu \mathrm{m}$ in diameter (7). The microsclerotia were stored in the dark at $24^{\circ} \mathrm{C}$ prior to use. Microsclerotia $(15 \mathrm{mg})$ were then added to crushed silica sand $(1 \mathrm{~g})$ particles sorted to between 75 and $106 \mu \mathrm{m}$. About $25 \mathrm{mg}$ of this mixture was added to a mesh bag (approximately $15 \times 20 \mathrm{~mm}$ ) prepared from polyester screening (Saatilene High Tech Fabric; $48-\mu \mathrm{m}$ pore size; SAATI S.p.A., Como, Italy), and the bag was sealed and used in solution bioassay and soil microcosm assay experiments to follow. The microsclerotia were then removed from the bioassays at various times. If the microsclerotia had not been in soil for at least 1 week, they were placed in nonamended soil for 1 week prior to determining viability. This was done to give them time to recover from stress of potential sublethal concentrations of VFAs before placing them on soil-pectate-tergitol agar (7). Microsclerotia placed immediately on this medium after exposure to sublethal concentrations of VFAs showed reduced germination compared with those given time to recover (12). Microsclerotia were distributed onto the medium with an Andersen

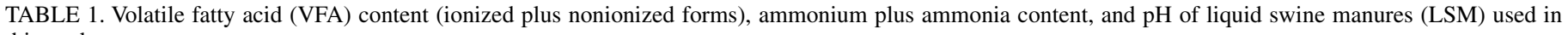
this study

\begin{tabular}{|c|c|c|c|c|c|c|c|c|c|c|}
\hline LSM & $\begin{array}{c}\text { Acetic } \\
(\mathrm{mM})\end{array}$ & $\begin{array}{l}\text { Propionic } \\
(\mathrm{mM})\end{array}$ & $\begin{array}{c}n \text {-Butyric } \\
(\mathrm{mM})\end{array}$ & $\begin{array}{l}\text { Isobutyric } \\
(\mathrm{mM})\end{array}$ & $\begin{array}{l}n \text {-Valeric } \\
(\mathrm{mM})\end{array}$ & $\begin{array}{l}\text { Isovaleric } \\
(\mathrm{mM})\end{array}$ & $\begin{array}{l}n \text {-Caproic } \\
(\mathrm{mM})\end{array}$ & $\begin{array}{l}\text { Total VFAs } \\
\qquad(\mathrm{mM})^{\mathrm{a}}\end{array}$ & $\begin{array}{c}\text { Ammonium + } \\
\text { ammonia }(\mathrm{mM})\end{array}$ & $\mathrm{pH}$ \\
\hline 96-01 & 270 & 59 & 16 & 38 & 18 & 3.6 & 9.0 & 400 & 500 & 7.9 \\
\hline $99-02$ & 87 & 42 & $\mathrm{NA}^{\mathrm{b}}$ & 8.7 & 3.9 & 12 & 2.1 & 160 & 270 & 7.9 \\
\hline 99-03 & 78 & 21 & NA & 4.0 & 2.5 & 5.0 & 2.1 & 110 & 100 & 7.6 \\
\hline $99-04$ & 48 & 14 & NA & 3.8 & 3.4 & 3.3 & 3.6 & 78 & 96 & 8.1 \\
\hline 99-05 & 7.4 & 1.3 & NA & 0.6 & 0.0 & 0.0 & 0.0 & 9.3 & 400 & 8.6 \\
\hline 00-01 & 48 & 7.7 & NA & 2.2 & 0.0 & 0.0 & 0.0 & 60 & 290 & 7.8 \\
\hline $00-02$ & 42 & 5.1 & NA & 1.6 & 0.0 & 0.0 & 0.0 & 50 & 320 & 7.8 \\
\hline $00-03$ & 41 & 13 & NA & 1.7 & 0.5 & 0.0 & 0.0 & 57 & 180 & 7.7 \\
\hline $00-05$ & 68 & 26 & NA & 5.8 & 4.8 & 4.3 & 4.2 & 110 & 190 & 7.0 \\
\hline 00-07 & 88 & 24 & NA & 9.1 & 4.3 & 8.4 & 4.8 & 140 & 300 & 7.5 \\
\hline 00-08 & 35 & 6.1 & NA & 1.3 & 0.0 & 0.0 & 1.7 & 44 & 190 & 7.8 \\
\hline 00-09 & 71 & 26 & NA & 5.2 & 3.0 & 5.7 & 5.1 & 120 & 260 & 7.5 \\
\hline $00-10$ & 33 & 7.8 & NA & 1.3 & 0.4 & 0.0 & 1.6 & 45 & 100 & 7.7 \\
\hline $00-15$ & 72 & 32 & NA & 18 & 7.9 & 20 & 9.8 & 160 & 450 & 7.5 \\
\hline $00-17$ & 120 & 52 & NA & 15 & 4.7 & 18 & 4.0 & 220 & 410 & 7.7 \\
\hline $00-20$ & 120 & 36 & NA & 12 & 2.0 & 15 & 2.1 & 190 & 460 & 7.2 \\
\hline $00-21$ & 100 & 26 & NA & 7.8 & 2.4 & 8.7 & 2.5 & 150 & 300 & 7.2 \\
\hline $00-22$ & 100 & 26 & NA & 7.8 & 2.5 & 9.3 & 1.8 & 150 & 360 & 7.3 \\
\hline $00-23$ & 49 & 11 & NA & 3.6 & 1.7 & 0.0 & 2.7 & 70 & 210 & 7.4 \\
\hline
\end{tabular}

a Includes all VFAs except $n$-butyric acid.

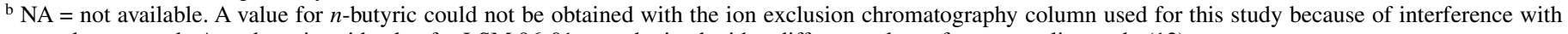
an unknown peak. An $n$-butyric acid value for LSM 96-01 was obtained with a different column from an earlier study (12).

TABLE 2. Characteristics of soils used in this study

\begin{tabular}{|c|c|c|c|c|c|c|c|}
\hline Location $^{\mathrm{a}}$ & Texture class & Clayb $\left.^{\mathrm{b}} \%\right)$ & $\operatorname{Sand}^{\mathrm{b}}(\%)$ & $\operatorname{Silt}^{\mathrm{b}}(\%)$ & Organic carbon ${ }^{\mathrm{c}}(\%)$ & $\begin{array}{l}\text { Water-capacity } \\
\text { (g/100 g dry soil) }\end{array}$ & $\mathrm{pH}^{\mathrm{e}}$ \\
\hline Site B & Loamy sand & 5 & 67 & 28 & 1.4 & 18 & 5.1 \\
\hline Site M & Sand & 4 & 90 & 6 & 0.86 & 16 & 5.5 \\
\hline Site K & Sandy loam & 8 & 67 & 25 & 1.2 & 14 & 5.8 \\
\hline Site F-I & Sand & 2 & 94 & 4 & 0.90 & 12 & 7.7 \\
\hline Site F-II & Sand & 2 & 95 & 3 & 0.88 & 12 & 7.9 \\
\hline Site Bw & Loam & 38 & 28 & 34 & 2.3 & 33 & 8.3 \\
\hline
\end{tabular}

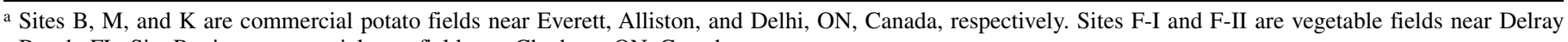
Beach, FL. Site Bw is a commercial corn field near Chatham, ON, Canada.

b Clay, sand, and silt were determined by the hydrometer method (11).

c Organic carbon was determined by the Walkley-Black wet oxidation-reduction method (16).

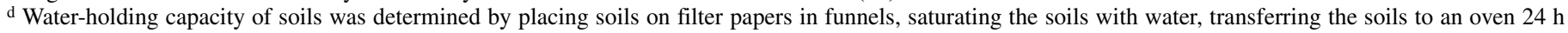
later, and calculating water loss.

e $\mathrm{pH}$ was determined from soil $(8 \mathrm{~g})$. Water $(40 \mathrm{ml})$ mixtures were shaken for $1 \mathrm{~h}$. 
cascade impactor having 0.81- and 1.18-mm-pore-diameter sieves (Andersen Instruments Inc., Smyrna, GA). Microsclerotia were incubated for 2 weeks in the dark at $24^{\circ} \mathrm{C}$ and then examined microscopically. A $0.25-\mathrm{cm}^{2}$ sectioned grid was placed on the base of a dissecting microscope. A plate was placed on the grid and scanned systematically at $\times 20$ magnification until 100 microsclerotia had been examined and scored for the formation of colonies. The viability of microsclerotia was determined as the percentage of the 100 examined that germinated to form colonies. Microsclerotia positioned too close to one another to differentiate as to which led to the formation of a colony were excluded from examination. Also excluded from examination were microsclerotia smaller than grains of sand because these become nonviable within a few weeks of being obtained from culture (7).

Soil microcosm assay. LSM, VFA mixture, and/or water were added to air-dried soil in polyethylene bags, which resulted in a moisture content of 50 to $70 \%$ of field capacity following vigorous shaking of the mixtures. Aliquots $(20 \mathrm{~g})$ were then placed in test tubes $(22 \times 150 \mathrm{~mm})$ and closed with plastic caps (Kim-Kap, Kimble, Toledo, $\mathrm{OH}$ ) that allowed for air exchange. Bags of microsclerotia were placed in the tubes prior to the addition of soil in order to ensure that the soil surrounded the bag. The tubes were gently tapped to settle the soil and incubated in the dark at $24^{\circ} \mathrm{C}$. Three replicates were sampled for each treatment at every sampling time. Water was added weekly to replace that lost by evaporation. This assay was used for all experiments involving soil.

Chemical analysis of LSM, bioassay solutions, and soil microcosms. Particulates in LSM and bioassay solutions were removed by centrifugation $(10 \mathrm{~min}$ at $10,600 \times g)$, the $\mathrm{pH}$ was determined with a polymer body $\mathrm{pH}$ electrode (Cole Parmer Instrument Co., Vernon Hills, IL), and some of the sample were used for determination of total VFAs, ammonia plus ammonium, and nitrite plus nitrous acid concentration by ion chromatography as described below.

A subsample $(8 \mathrm{~g})$ of soil from soil microcosm assays was added to cold water $(40 \mathrm{ml})$ in plastic sacks. The sacks were sealed and the slurry was mechanically disrupted (30 s) with a Stomacher homogenizer (Seward Medical, London, UK). The sacks were placed on an orbital shaker $(200 \mathrm{rpm})$ for $1 \mathrm{~h}$ at $4^{\circ} \mathrm{C}$. The sacks were then removed from the cold, mechanically disrupted again, and allowed to sit at room temperature for $1 \mathrm{~h}$, and the $\mathrm{pH}$ was determined. Some of this mixture was used for analysis by ion chromatography.

The concentrations of ionized plus nonionized forms of individual VFAs were determined by ion exclusion chromatography, and those of ammonium plus ammonia and nitrous acid plus nitrite were determined by ion exchange chromatography. Both methods used chemical suppression and conductivity detection (Dionex Model 100, Dionex Corp., Sunnyvale, CA). The analytical columns used were IonPac ICE-AS1 for VFAs, IonPac CS12A for cations, and IonPac AS-14 for anions along with an AMMS ICE II chemical suppressor (Dionex Corp.). Samples contained in vials were introduced to the ion chromatograph using an autosampler equipped with a refrigerated chamber housing the vials (Waters 717plus, Waters Associates, Milford, MA). The concentrations (in millimolar, $\mathrm{mM}$ ) of nonionized VFAs, ammonia, and nitrous acid were estimated with the Henderson-Hasselbalch equation as previously described $(12,13)$.

Toxicity of LSM and a VFA mixture in an acid soil. Toxicity to microsclerotia of LSM 96-01 and a VFA mixture was determined in soil from site B. The mixture of VFAs was prepared with individual VFA components (Sigma Chemical, St. Louis) at the same concentration found in the manure (12). The $\mathrm{pH}$ of the VFA mixture was 5.1. Because $\mathrm{pH}$ determines the amount of VFAs in the nonionized and toxic form (12), the $\mathrm{pH}$ of the LSM was reduced to 5.1 with concentrated sulfuric acid to match that of the VFA mixture and site B soil. LSM ( $\mathrm{pH} \mathrm{5.1)} \mathrm{or} \mathrm{the} \mathrm{VFA}$ mixture and water were added to air-dried soil to give LSM and
VFA mixture concentrations of $0,10,20$, and $40 \%$ (wt/wt) soil moisture and a soil moisture level of $10 \%(\mathrm{wt} / \mathrm{wt})$ soil. Calculating LSM and VFA concentrations based on percent (wt/wt) soil moisture ensured accurate concentrations for each soil, irrespective of soil moisture levels. At $10 \%$ soil moisture, the amounts of manure added were $0,1,2$, and $4 \%$ (wt/wt) soil. Assuming a soil bulk density of $1.33 \mathrm{~g} / \mathrm{cm}^{3}$ and incorporation of manure to a depth of $15 \mathrm{~cm}$, the equivalent rates per hectare would be approximately $0,20,40$, and $80 \mathrm{hl}$, respectively. Microsclerotia were placed in the soil for 1 day, removed, and placed in nonamended soil for 1 week before their germination was determined. Soil $\mathrm{pH}$ was measured at day 0 and day 1 . This and each subsequent experiment reported were performed twice, with three replicates each.

Comparison of LSMs for VFA content and toxicity in an acid soil. Toxicity of 19 LSMs to microsclerotia was determined in soil from site B. LSM was added to air-dried soil to give a concentration of 0 and $30 \%$ (wt/wt) soil moisture and a soil moisture level of $10 \%(\mathrm{wt} / \mathrm{wt})$ soil. Microsclerotia were placed in the soil at day 0 and removed 1 week later. Soil $\mathrm{pH}$ was measured at day 0 and day 7. The total concentration of nonionized VFAs in the LSM-soil mixtures at day 0 was determined with the HendersonHasselbalch equation, the concentration of individual VFAs (ionized plus nonionized forms) in the soil water component (calculated from the values in Table 1), and the $\mathrm{pH}$ of the mixtures.

Generation of nitrous acid after addition of LSM to acid soils. Potential nitrous acid toxicity to microsclerotia after addition of LSM to two soils (sites M and K) was tested. LSM 96-01 and water were added to air-dried soil to give LSM concentrations of $0,10,20$, and $40 \%$ (wt/wt) soil moisture and a soil moisture level of $10 \%(\mathrm{wt} / \mathrm{wt})$ soil. The equivalent rate per hectare would be the same as described previously for site B soil. Microsclerotia were placed in the soils at day 0 and removed 1 and 6 weeks later. Soil $\mathrm{pH}$, soil moisture levels, and nitrite plus nitrous acid concentration in the soil water component were determined at weeks 0 , $1,2,4$, and 6 . The concentration of nitrous acid in soil was determined with the Henderson-Hasselbalch equation, the measured concentration of nitrite plus nitrous acid in the soil water component, and the $\mathrm{pH}$ of the soil.

Toxicity of ammonia in LSM in alkaline soils. Toxicity of LSM to microsclerotia was tested in three soils of high $\mathrm{pH}$ (sites F-I, F-II, and Bw). LSM 96-01 and water were added to air-dried soil to give LSM concentrations of $0,10,20$, and $40 \%$ (wt/wt) soil moisture and a soil moisture level of $6 \%$ (wt/wt) soil for F-I and F-II soils and $20 \%$ for Bw soil. At $6 \%$ soil moisture, the amounts of manure added were $0,0.6,1.2$, and $2.4 \%$ (wt/wt) soil, which would be equivalent to approximately $0,11.5,23$, and $46 \mathrm{hl} / \mathrm{ha}$, respectively. At $20 \%$ soil moisture, the amounts of manure added were $0,2,4$, and $8 \%$ (wt/wt) soil, which would be equivalent to approximately $0,40,80$, and $160 \mathrm{hl} / \mathrm{ha}$, respectively. Microsclerotia were placed in the soils at day 0 and removed 1 week later. Soil $\mathrm{pH}$, soil moisture levels, and ammonia plus ammonium concentration in the soil water component were determined at days $0,1,3$, and 7 . The concentration of ammonia in soil was determined with the Henderson-Hasselbalch equation, the measured concentration of ammonia plus ammonium in the soil water component, and the $\mathrm{pH}$ of the soil.

Toxicity of LSM as a function of pH. Toxicity to microsclerotia of LSM over a $\mathrm{pH}$ range of 3 to 9 was carried out using a solution bioassay. In one experiment, LSM 96-01 was added (10\%, $\mathrm{vol} / \mathrm{vol}$ ) to citric acid- $\mathrm{Na}_{2} \mathrm{HPO}_{4}$-buffered solutions ( $\mathrm{pH} 3$ to 7 at $0.5 \mathrm{pH}$ increments). In a second experiment, LSM 96-01 and an ammonium chloride solution with an equivalent ammonium concentration as in the manure were added $(10 \%, \mathrm{vol} / \mathrm{vol})$ to citric acid- $\mathrm{Na}_{2} \mathrm{HPO}_{4}$-buffered solutions ( $\mathrm{pH}$ 7.0, 7.5, and 8.0) and glycine- $\mathrm{NaOH}$-buffered solutions $(\mathrm{pH} 8.5$ and 9.0). The solutions were filter sterilized and added $(9 \mathrm{ml})$ to three sterile screw-cap tubes per treatment. One mesh bag containing microsclerotia was submerged in the solution and one bag was suspended in the head 
space of each tube, and the tubes were closed and incubated for 1 day in the dark at $24^{\circ} \mathrm{C}$. The mesh bags were retrieved from the solutions, rinsed with sterile distilled water, dried at room temperature for $3 \mathrm{~h}$, and placed into soil for 1 week prior to determining microsclerotia germination. Solution $\mathrm{pH}$ was measured at day 0 and day 1. The total concentration of nonionized VFAs and ammonia in the solutions at day 0 was determined with the Henderson-Hasselbalch equation, the concentration of individual VFAs (ionized plus nonionized forms) and ammonia plus ammonium in the solutions (calculated from the values in Table 1), and the $\mathrm{pH}$ of the solutions.

Statistical analysis. The data for microsclerotia germination were analyzed using SigmaStat (Jandel Scientific Software, San Rafael, CA). Percentage data were tested for normality and were arcsine transformed before analysis, if required. Mean comparisons were carried out using the Student-Newman-Keuls method $(P=0.05)$.

\section{RESULTS}

Toxicity of LSM and a VFA mixture in an acid soil. The toxicity of LSM 96-01 and a VFA mixture equivalent to that in the LSM were added to an acid soil to compare their toxicity in soil. Germination of microsclerotia declined with increasing concentrations of LSM or the VFA mixture (Fig. 1). Both LSM and the VFA treatments reduced germination to about the same extent. The $40 \%$ ([wt/wt] soil moisture) LSM and equivalent VFA treatments reduced germination by $90 \%$ after a 1 -day exposure compared with that of the control, and the $10 \%$ treatments reduced germination by about $45 \%$ (Fig. 1).

Comparison of LSMs for VFA content and toxicity in an acid soil. Nineteen LSMs collected from different farm operations were added to site $\mathrm{B}$ soil ( $\mathrm{pH}$ 5.1). In all instances, addition of manure to soil resulted in an immediate increase in soil $\mathrm{pH}$ in the range of 0.2 to 1.3 (Fig. 2A). The resulting concentrations of total nonionized forms of VFAs in the water matrix of each soilLSM mixture are shown in Figure 2B. They ranged from a high of $8 \mathrm{mM}$ to a low of $0.2 \mathrm{mM}$. Soil-LSM mixtures with a concentration of $2.7 \mathrm{mM}$ or higher resulted in almost $100 \%$ reduction in germination of $V$. dahliae microsclerotia compared with that of the control (Fig. 2C). Mixtures with less than 1.9 mM VFAs resulted in practically no reduction in germination. The soil-LSM 00-23 mixture with a VFA concentration $(2.4 \mathrm{mM})$ between this range resulted in a $40 \%$ reduction in germination.

Generation of nitrous acid after addition of LSM to acid soils. LSM 96-01 was added to site $\mathrm{M}$ and $\mathrm{K}$ soils which had $\mathrm{pH}$ values of 5.5 and 5.8, respectively. The results were similar for both soils so results from only one of the soils (site K) are shown. The LSM treatments reduced the germination of microsclerotia buried in the soil by 10 to $20 \%$ by week 1 compared with that of the control (Fig. 3A). By week 6, germination in the 10 and $20 \%$ LSM treatments ([wt/wt] soil moisture) had not changed much from week 1, whereas germination retrieved from the 40\% LSM treatment was reduced to zero (Fig. 3A). Soil pH for all LSM treatments increased by week 1 and then decreased to levels below the control by week 2 or 3 (pH 5.7 versus 4.9, Fig. 3B). The $40 \%$ LSM treatment reached the highest $\mathrm{pH}$ of 7.4 and then declined to just under 5 . Nitrous acid $(0.06 \mathrm{mM})$ was detected by week 4 for the $40 \%$ LSM treatment but not in the other treatments (Fig. 3C).

Toxicity of ammonia in LSM in alkaline soils. LSM 96-01 was added to site F-I, F-II, and Bw soils which had $\mathrm{pH}$ values of 7.7, 7.9, and 8.3, respectively. LSM 96-01 was not toxic to microsclerotia in site Bw soil (data not shown). Microsclerotia germination in the F-I and F-II soils was reduced to a similar extent so results from only one of the soils (F-II) are shown. Germination of microsclerotia in the $40 \%$ ([wt/wt] soil moisture) LSM treatment was reduced by $80 \%$ after a 1 -week exposure compared with that of the control (Fig. 4A). The 20\% LSM treatment reduced germination by $20 \%$, and the $10 \%$ LSM treatment had no effect. Soil $\mathrm{pH}$ for all LSM treatments increased by day 1 to $8.4,8.7$, and 8.9 with the 10, 20, and 40\% LSM, respectively (Fig. 4B). The $\mathrm{pH}$ levels returned to control levels by day 7 with the lower rates of LSM, but with the $40 \%$ treatment, $\mathrm{pH}$ remained at 8.9 for at least 3 weeks and then declined slowly thereafter. The concentration of ammonia in the soil with the $40 \%$ LSM treatment reached $14 \mathrm{mM}$ by day 1 and climbed to a concentration of $29 \mathrm{mM}$ by week 1 where it remained until week 3 (Fig. 4C). With the $20 \%$ LSM treatment, a short burst of ammonia was seen that reached a concentration of $10 \mathrm{mM}$. No ammonia was present in the $10 \%$ LSM or control treatments. The expected concentration of ammonia at day 0 for the $40 \%$ LSM treatment was $17 \mathrm{mM}$ based on the concentration of ammonium plus ammonia in LSM 96-01 $(500 \mathrm{mM})($ Table 1$)$ and the $\mathrm{pH}(8.2)$ of the soil-manure at day 0 . This was close to the measured value of $14 \mathrm{mM}$.

Toxicity of LSM as a function of pH. The toxicity of LSM 96-01 to $V$. dahliae microsclerotia was determined in a solution assay over a $\mathrm{pH}$ range of 3 to 9 (Fig. 5A and B). The toxicity of the manure in solution (Fig. 5A) or in the atmosphere above the solution (Fig. 5B) increased as the $\mathrm{pH}$ decreased below 6 or rose above 8 . Complete kill in the manure solution was obtained at $\mathrm{pH}$ 5 , where the nonionized form of the VFAs reached $15 \mathrm{mM}$ (Fig. 5C), and at $\mathrm{pH} 9$, where ammonia levels reached $25 \mathrm{mM}$ (Fig. 5C). In the head space, kill occurred in a similar trend but complete kill was only obtained at $\mathrm{pH}$ values of 3 and 9 . The toxicity of LSM in solutions at low $\mathrm{pH}$ was previously shown to be due to VFAs (12). We also determined if ammonia accounted for all the toxicity observed at high $\mathrm{pH}$ by comparing the toxicity of LSM 96-01 with that of an ammonium chloride solution with an equivalent concentration of ammonium as found in the manure (Fig. 5A and B). Germination of microsclerotia in the solutions and in the atmosphere above the solutions declined in an identical manner with both the LSM and ammonium chloride treatments as the $\mathrm{pH}$ levels increased from 7 to 9 .

\section{DISCUSSION}

In this study, we identified three mechanisms by which LSM can kill microsclerotia of $V$. dahliae in soil. The presence of lethal

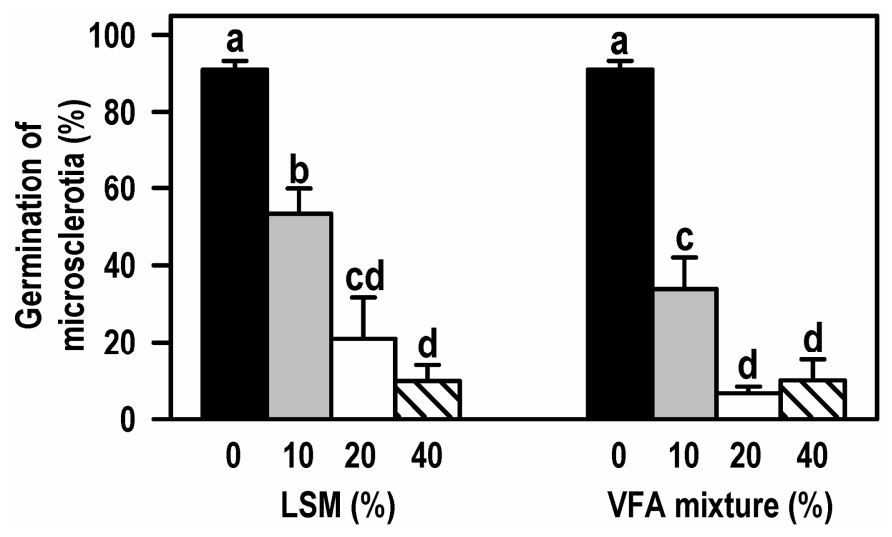

Fig. 1. Comparison of the toxicity of liquid swine manure (LSM 96-01, pH reduced to 5.1 with sulfuric acid) and a mixture of volatile fatty acids (VFAs, $\mathrm{pH}$ 5.1) on Verticillium dahliae microsclerotia in soil from a commercial potato field (site $\mathrm{B}, \mathrm{pH} 5.1$ ). The mixture of VFAs was prepared with individual VFA components at the same concentration found in the manure (Table 1). LSM 96-01 or the VFA mixture and water were added to air-dried soil to give LSM and VFA mixture concentrations of $0,10,20$, and $40 \%$ (wt/wt) soil moisture and a soil moisture level of $10 \%$ (wt/wt) soil. Microsclerotia were placed in soil for 1 day, removed, and placed in nonamended soil for 1 week before their germination was determined. Error bars represent \pm 1 standard error of the mean of two experiments $(n=6)$. Means with the same letter are not significantly different $(P=0.05$, Student-Newman-Keuls method). 
VFAs in LSM can now be attributed to the kill of microsclerotia observed within a few days after addition of manure to acid soils $(1,2)$. Until now, such toxicity to microsclerotia was demonstrated only in solution assays (12). In this study, the toxicity of an LSM and a VFA mixture equivalent to that in the manure was shown to be the same and to occur within 1 day when added to an acid soil.

VFAs were also proven to be the main toxic components in 19 LSMs added $(30 \%$ [wt/wt] soil moisture; equivalent to approximately $60 \mathrm{hl} / \mathrm{ha}$ ) to the same acid soil. About $60 \%$ of the manures tested reduced germination of microsclerotia to near zero after a 1-week exposure. Addition of these manures to soil resulted in a total nonionized VFA concentration of 2.7 to $8 \mathrm{mM}$ in the water component of the soil-LSM mixtures at day 0. The six LSMs that did not reduce microsclerotia germination whatsoever resulted in soil-LSM mixtures that had the lowest concentration of total nonionized VFAs ( 0.2 to $1.9 \mathrm{mM}$ ), confirming the role of VFAs in microsclerotia mortality. The difference between the concentration of nonionized VFAs that resulted in $100 \%$ kill of microsclerotia and those that had no affect was surprisingly only about $1 \mathrm{mM}$. Such a narrow range of activity was found previously in solution assays with microsclerotia germination after a 4-day exposure to acetic acid where a $3 \mathrm{mM}$ total concentration resulted in a $20 \%$ reduction in germination, whereas a $5 \mathrm{mM}$ solution resulted in $95 \%$ reduction (12).

These results indicate that the effectiveness of VFAs in LSM to kill microsclerotia in acid soils depends upon many factors. First, the quantity and composition of VFAs in manure determines the potential for the manure to be effective in killing microsclerotia. Total VFA concentration in the 19 LSMs tested in this study ranged from 9.3 to $400 \mathrm{mM}$. We are currently conducting a detailed survey of swine operations to determine what factors lead to such large variability in the VFA content of LSMs. The type of VFAs in manure is also important because VFAs such as $n$ valeric, isovaleric, and $n$-caproic are more toxic to microsclerotia than acetic, propionic, $n$-butyric, and isobutyric (12). The total concentration of $n$-valeric plus isovaleric and $n$-caproic ranged from 0 to $30 \mathrm{mM}$ in the manures tested in this study. This information will be necessary to maximize the VFA content of LSM and for predicting which LSMs may be useful for control of V. dahliae.

The $\mathrm{pH}$, buffering capacity, and amount of LSM added to a soil greatly affect its efficacy to kill microsclerotia. The $\mathrm{pH}$ of the 19

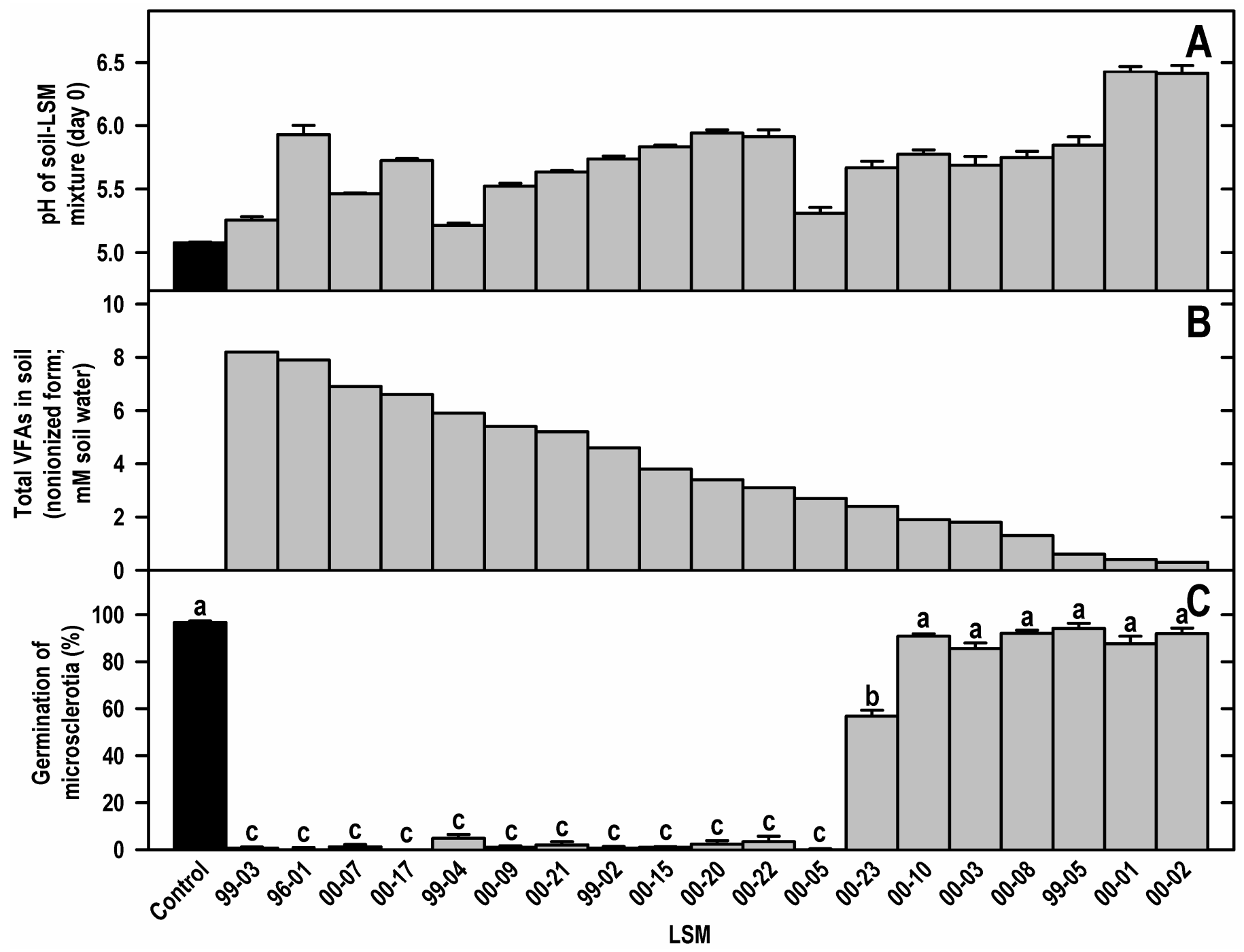

Fig. 2. Comparison of liquid swine manures (LSMs) for A, effect on soil $\mathrm{pH}$; $\mathbf{B}$, total VFA (nonionized form) content; and $\mathbf{C}$, toxicity to Verticillium dahliae microsclerotia in soil from a commercial potato field (site B). LSM and water were added to air-dried soil to give an LSM concentration of $30 \%$ (wt/wt) soil moisture and a soil moisture level of $10 \%$ (wt/wt) soil. Microsclerotia were placed in soil at day 0 and removed 1 week later. B, The total concentration of nonionized VFAs in the LSM-soil mixtures at day 0 was determined with the Henderson-Hasselbalch equation, the concentration of individual VFAs (acetic, propionic, isobutyric, $n$-valeric, isovaleric, and $n$-caproic) in the mixtures (calculated from the values in Table 1), and the $\mathrm{pH}$ of the mixtures. Error bars represent \pm 1 standard error of the mean of two experiments $(n=6)$. Means for microsclerotia germination with the same letter are not significantly different $(P=0.05$, Student-Newman-Keuls method). 
LSMs used in this study ranged from 7.0 to 8.6. LSM pH is determined, at least in part, by the ratio of ammonia and VFAs in the manure (9). Addition of these manures ( $60 \mathrm{hl} / \mathrm{ha}$ rate) to a soil of $\mathrm{pH} 5.1$ resulted in soil-LSM mixtures with $\mathrm{pH}$ values from 5.2 to 6.4. This variation in $\mathrm{pH}$ affected the concentration of VFAs present in the nonionized form in the soil and thus the toxicity of the manure. There is a direct relationship between the volume of manure added and toxicity to microsclerotia up to the point when the resulting soil-LSM mixture $\mathrm{pH}$ increases to a level at which the concentration of nonionized VFAs falls below toxic levels.

Efficacy of LSM to kill microsclerotia is most influenced by soil $\mathrm{pH}$ and buffering capacity. LSM will be most effective in an
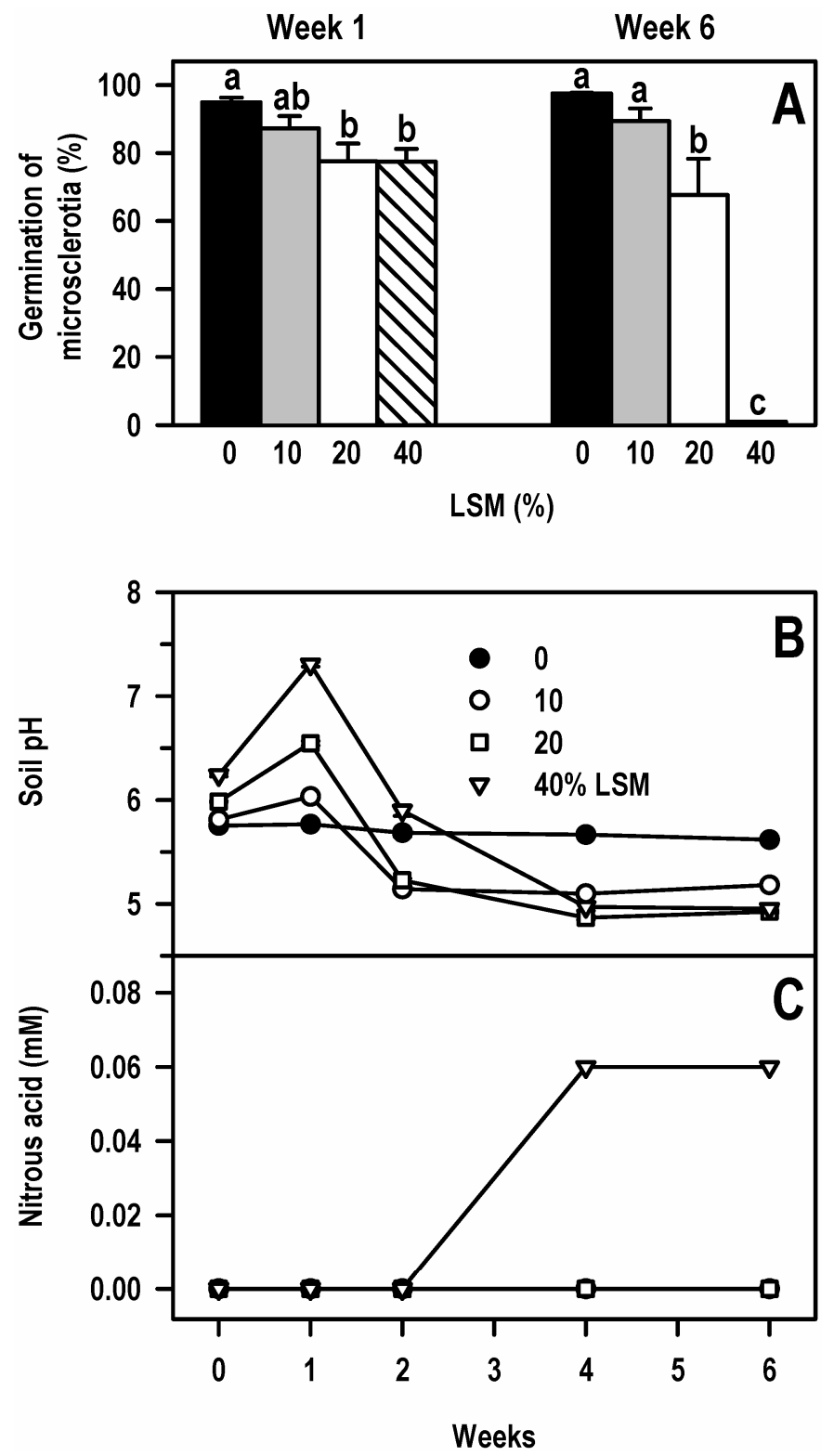

Fig. 3. Effect of liquid swine manure (LSM) on A, viability of Verticillium dahliae microsclerotia; $\mathbf{B}$, soil $\mathrm{pH}$; and $\mathbf{C}$, soil nitrous acid concentration in soil from a commercial potato field (site K). LSM 96-01 and water were added to air-dried soil to give LSM concentrations of $0,10,20$, and $40 \%$ (wt/wt) soil moisture and a soil moisture level of $10 \%(w t / w t)$ soil. Microsclerotia were placed in soil at day 0 and removed 1 and 6 weeks later. The concentration of nitrous acid in soil was determined with the HendersonHasselbalch equation, the measured concentration of nitrite plus nitrous acid in the soil water component, and the $\mathrm{pH}$ of the soil. Error bars represent \pm 1 standard error of the mean of two experiments $(n=6)$. Means for microsclerotia germination within each week with the same letter are not significantly different $(P=0.05$, Student-Newman-Keuls method). acid soil that has a high buffering capacity such that addition of the manure will not raise its $\mathrm{pH}$ and thereby reduce the concentration of nonionized VFAs present. The slower the rise in $\mathrm{pH}$, the longer the exposure of pathogen resting structures to VFAs. This can have practical consequences on effective rates of manure addition because the toxicity of acetic acid to $V$. dahliae microsclerotia has been shown to be a function of acid concentration and duration of exposure (12).

The moisture content and temperature of the soil can also affect the efficacy of LSM to kill microsclerotia (2). Addition of LSM to a dry and warm soil increases the effectiveness by increasing the concentrations of VFAs in the soil solution. VFAs in wet soils undergo greater dilution. Increasing temperature has the effect of al-
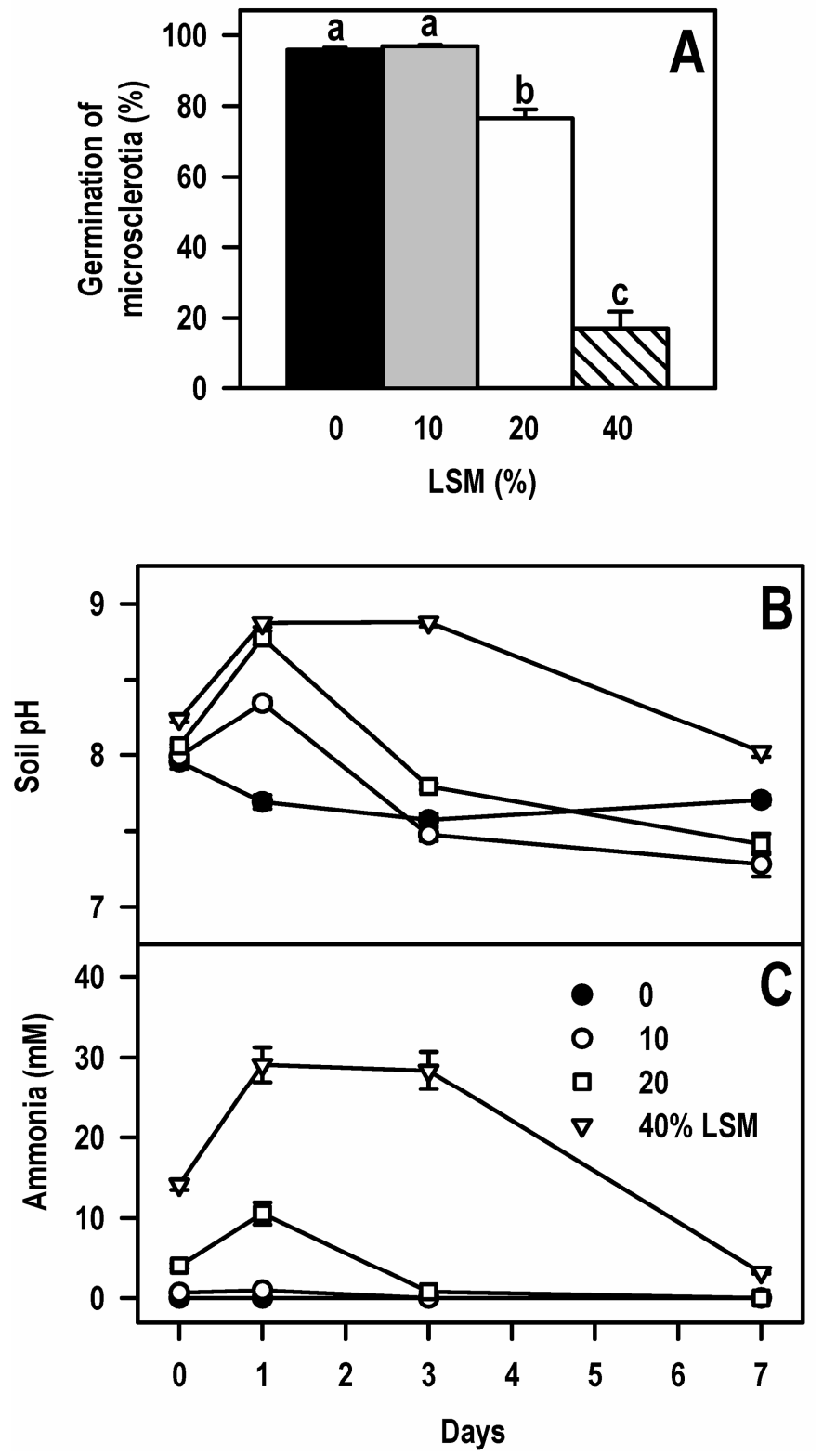

Fig. 4. Effect of liquid swine manure (LSM) on A, viability of Verticillium dahliae microsclerotia; $\mathbf{B}$, soil $\mathrm{pH}$; and $\mathbf{C}$, soil ammonia concentration in soil from a commercial vegetable field (site F-II). LSM 96-01 and water were added to air-dried soil to give LSM concentrations of 0, 10, 20, and 40\% (wt/wt) soil moisture and a soil moisture level of $6 \%$ (wt/wt) soil. Microsclerotia were placed in soil at day 0 and removed 1 week later. The concentration of ammonia in soil was determined with the Henderson-Hasselbalch equation, the measured concentration of ammonia plus ammonium in the soil water component, and the $\mathrm{pH}$ of the soil. Error bars represent \pm 1 standard error of the mean of two experiments $(n=6)$. Means for microsclerotia germination with the same letter are not significantly different $(P=0.05$, StudentNewman-Keuls method). 
tering the dissociation constant of weak acids such as VFAs so as to form greater amounts of nonionized forms ( $\mathrm{pKa}$ increases with temperature more for weak than for strong acids) (10).

The rate of degradation of VFAs in soil is also expected to significantly impact the disease control potential of LSM. VFAs are readily metabolized by microorganisms in soil (9). Measurements of the rate of degradation carried out on some of the soils tested in this study showed that the VFAs from LSM became undetectable between 2 and 4 days after application (data not shown). The concentration of nonionized VFAs present in soil need only be determined for up to this time frame.

Soil texture and organic content, however, do not affect the efficacy of VFAs in LSM to kill $V$. dahliae microsclerotia (2). When five soils ranging in texture from sand to loam and organic carbon content from 1.4 to $6 \%$ were made equal with respect to $\mathrm{pH}$ and LSM concentration, LSM killed microsclerotia to a similar extent in all soils. The water-holding capacity of a soil, which is partially determined by organic carbon content, however, is

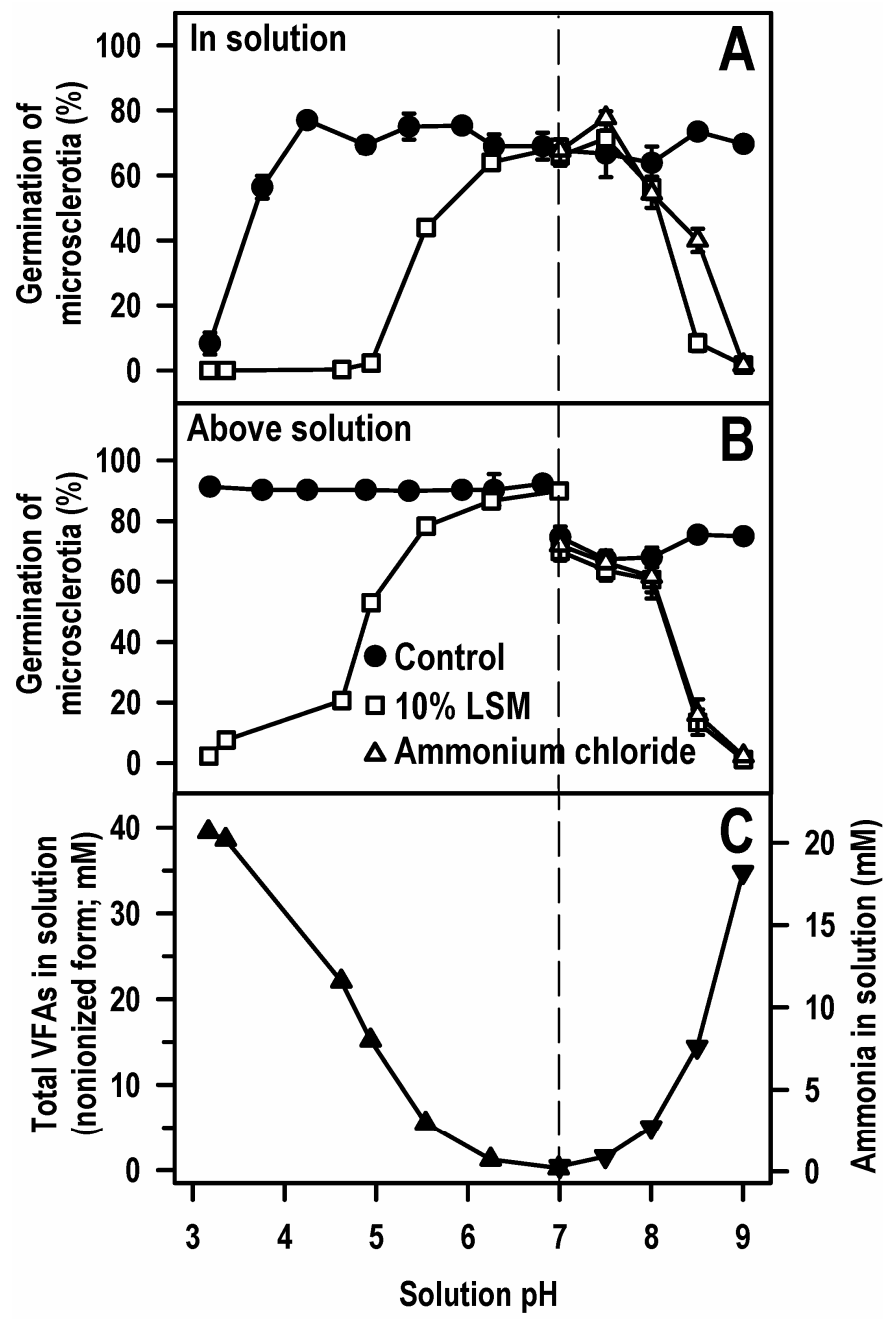

Fig. 5. Influence of $\mathrm{pH}$ on liquid swine manure (LSM) and ammonium chloride toxicity to Verticillium dahliae microsclerotia. LSM 96-01 was added $(10 \%, \mathrm{vol} / \mathrm{vol})$ to citric acid- $\mathrm{Na}_{2} \mathrm{HPO}_{4}$-buffered solutions ( $\mathrm{pH} 3$ to 7$)$ in one experiment; and LSM 96-01 and ammonium chloride were added to citric acid- $\mathrm{Na}_{2} \mathrm{HPO}_{4}$-buffered solutions ( $\mathrm{pH} 7$ to 8 ) and glycine-NaOH-buffered solutions ( $\mathrm{pH} 8.5$ and 9) in a second experiment. Microsclerotia were placed $\mathbf{A}$, in and $\mathbf{B}$, above the solutions for 1 day, removed, and placed in soil for 1 week before their germination was determined. C, The total concentration of nonionized volatile fatty acids (VFAs) and ammonia in the solutions at day 0 was determined with the Henderson-Hasselbalch equation, the concentration of individual VFAs (acetic, propionic, isobutyric, $n$-valeric, isovaleric, and $n$ caproic) and ammonia plus ammonium in the solutions (calculated from the values in Table 1), and the $\mathrm{pH}$ of the solutions. Error bars represent \pm 1 standard error of the mean of two experiments $(n=6)$. important because a higher soil moisture content means that more LSM is needed.

The delayed kill of microsclerotia 3 to 6 weeks after application of LSM to some moderately acid soils was identified here to be associated with the formation of nitrous acid. More than sufficient amounts of nitrous acid were detected $(0.06 \mathrm{mM})$ to kill microsclerotia. In a previous study with solution assays, $0.03 \mathrm{mM}$ nitrous acid was sufficient to kill microsclerotia (13). However, only the highest concentration of LSM tested ( $80 \mathrm{hl} / \mathrm{ha}$ ) resulted in accumulation of enough nitrous acid to kill microsclerotia. This rate is considered environmentally unsafe in sandy soils, and thus such a mechanism seems not to be readily exploited, at least in the soils tested here.

The formation of ammonia after addition of LSM (40\% [wt/wt] soil moisture, equivalent to approximately $46 \mathrm{hl} / \mathrm{ha}$ ) to a sandy soil of $\mathrm{pH} 7.9$ and the resulting $80 \%$ kill of microsclerotia within 1 week was readily predictable based on earlier studies with high nitrogen-containing amendments $(13,14)$. The ammonia concentration present $(29 \mathrm{mM})$ in the water component of the soil in this study was similar to that needed to kill microsclerotia in soil with high nitrogen-containing amendments $(13,14)$. Based on the fact that an LSM and an ammonium chloride solution with the same ammonium concentration as the LSM resulted in identical levels of ammonia being generated and similar kill of microsclerotia, we can assume that ammonia accounted for all the microsclerotia kill observed with LSM at high $\mathrm{pH}$.

The amount of LSM needed (46 hl/ha) to give $80 \% \mathrm{kill}$ in the sandy alkaline soil due to ammonia was about the same as that needed (40 hl/ha) for $80 \%$ kill in the acid soil due to VFAs. The concentration of ammonium plus ammonia in the 19 manures tested in this study ranged from 100 to $500 \mathrm{mM}$ with an average of $280 \mathrm{mM}$. Since the manure tested in the alkaline soil had $500 \mathrm{mM}$ concentration of ammonium plus ammonia, not all manures may have enough ammonia to provide activity but many would. The reason for this range of ammonium concentration is being investigated as part of the survey of swine operations discussed earlier. This information will be important for prediction of which LSMs may be useful to control plant disease in alkaline soils.

Addition of LSM did not result in ammonia toxicity in all alkaline soils tested in this study. Ammonia was not released at high concentration in a soil with high organic content and did not result in reduction of microsclerotia germination. Tenuta and Lazarovits (15) have shown that in addition to $\mathrm{pH}$, organic matter content is an equally important factor in regulation of the quantity of ammonia released from a high nitrogen-containing organic product.

Several soils were used in this study to demonstrate the effect of soil $\mathrm{pH}$ on the differing modes of action of LSM in killing microsclerotia. The soils used covered a range of soil $\mathrm{pH}$. Site B was a very acid soil ( $\mathrm{pH} 5.1$ ), sites $\mathrm{K}$ and $\mathrm{M}$ moderately acid ( $\mathrm{pH} 5.5$ to 5.8), and sites F-I, F-II, and Bw alkaline ( $\mathrm{pH} 7.7$ to 8.3). The results demonstrate toxicity to microsclerotia in LSM-amended soil by VFAs, nitrous acid, and ammonia accumulation in the very acid, moderately acid, and alkaline soils, respectively. If two modes of action can occur in some soils, it is of notable interest as it may be a means to ensure thorough disinfestations of microsclerotia in surface soils or possibly provide broad-spectrum control of a range of pathogens, pests, and weeds. Our study of VFA toxicity in site B soil was terminated 7 days after LSM addition, sufficient for determination of VFA toxicity, but 1 to 3 weeks prior to expected nitrous acid accumulation from nitrification $(13,15)$ of mineralized manure- $\mathrm{N}$ in acid soil. In a previous study, we followed the effect of LSM on the $\mathrm{pH}$ of site B soil for 6 weeks (2). Soil $\mathrm{pH}$ initially increased but then declined to just below pH 5 after 4 weeks, depending on the amount of LSM added and the soil moisture content. In that study, we did not measure the concentration of nitrous acid in the soil, but the fact 
that the $\mathrm{pH}$ decreased to below 5 means there is a potential for nitrous acid toxicity in this soil in addition to VFA toxicity.

These findings and those presented previously $(2,12)$ indicate soil $\mathrm{pH}$ to be the overriding factor determining the mode of action of LSM in killing microsclerotia of $V$. dahliae. In a very acid soil for potato production (site $\mathrm{B}, \mathrm{pH}$ of water about 5.1 or $\mathrm{pH}$ of $0.01 \mathrm{M} \mathrm{CaCl}_{2}$ about 4.6), LSM addition at about $55 \mathrm{hl} / \mathrm{ha}$ killed microsclerotia in a field (1), the effect can now be attributed to generation of associated VFAs lethal to microsclerotia. In Canada, such very acid soils are in the sand texture classes and have low $\mathrm{pH}$ buffering ability because of low organic matter and clay contents. They are ideally suited for use of LSM to control soilborne plant pathogens because VFAs in the manure are immediately converted to associated forms lethal to microsclerotia in soil but within days degraded by soil microorganisms, leaving no residual phytotoxic effect to the planted crop.

In moderately acid soil ( $\mathrm{pH}$ of water up to 6.0 or $\mathrm{pH}$ of $0.01 \mathrm{M}$ $\mathrm{CaCl}_{2}$ about 5.5), there is only a small amount of the VFAs in the nonionized form and thus little VFA toxicity. However, there is rapid nitrification of ammoniacal nitrogen from LSM or from other amendments including fertilizers and animal rendering products $(13,15)$ that results in the accumulation of nitrous acid and the death of microsclerotia. This mode of action of LSM to disinfest soil of pathogens and pests relies on application of the amendments weeks prior to planting. In temperature climates such as Canada, amendment following crop harvest is likely a more effective approach to generating nitrous acid toxicity. Soils are sufficiently warm for several weeks for nitrification $\left(>10^{\circ} \mathrm{C}\right)$, populations of nitrifying bacteria are high, and soil $\mathrm{pH}$ is at its lowest point in the year due mainly to acidification from nitrification of spring applied fertilizer-N.

In alkaline soil ( $\mathrm{pH}$ of water above 8.0 or $\mathrm{pH}$ of $0.01 \mathrm{M} \mathrm{CaCl}_{2}$ above 7.5), the dissociation of ammonium to form ammonia can result in ammonia killing microsclerotia of $V$. dahliae within days of LSM addition to soil. The increase in $\mathrm{pH}$ of 0.4 to 1 unit within a day of addition of LSM to the alkaline soils tested would further promote the accumulation of ammonia. The increase in $\mathrm{pH}$ is likely due to either the degradation of VFAs reducing acidity of soil solution or the mineralization of organic $\mathrm{N}$ in the manure producing ammonia. Regardless, a rise in $\mathrm{pH}$ above 8.0 following addition of ammonia producing amendments is modulated by the presence of organic matter $(14,15)$; sand soils with their organic matter content promote ammonia accumulation. Relying on ammonia to disinfest soil of pathogens and pests can be done several weeks prior to spring planting because $\mathrm{pH}$ and ammonia levels in LSM-amended soil drop to that prior to amendment within 1 week of LSM addition. As a spring preplant amendment, LSM has the benefit of providing a source of nitrogen fertility. Addition in fall may disinfest soil equally well but is prone to loss of nitrogen in LSM to leaching over winter.

It should be noted that contrary to the effect of chemical fumigants, VFAs and other substrates in LSM support the growth of populations of heterotrophic soil microorganisms (1). The implications to soil quality and long-term overall disease management of using a product such as LSM to disinfest soil and stimulate microbial populations rather than partial sterilization of soil typical with chemical fumigants are unknown.

This study has shown that LSM can kill microsclerotia of $V$. dahliae by at least three mechanisms: VFA, nitrous acid, and ammonia toxicity. The characteristics of the manure (VFA content, ammonium content, and $\mathrm{pH} / \mathrm{buffering}$ capacity) determine the potential for formation of lethal compounds in soil. The soils chemical ( $\mathrm{pH}$, physical, organic matter content, buffering capacity, moisture content, and temperature) and biological properties (degradation of VFAs and nitrification rate) then determine the actual degree of formation and concentration of the lethal compounds. Understanding the factors responsible for the generation of each mode of action is critical if amendments such as LSM are to be used to control important soilborne plant pathogens.

\section{ACKNOWLEDGMENTS}

This work was supported by grants from CanAdapt, Ontario Pork, Ontario Potato Marketing Board, The Producers Yield Club (Prince Edward Island), and AAFC MII. We thank Y. Lin, I. Lalin, M. MacInnis, V. Seguin, P. Bustard, A. Brown, P. Martin, and M. Hleba for excellent technical assistance.

\section{LITERATURE CITED}

1. Conn, K. L., and Lazarovits, G. 1999. Impact of animal manures on Verticillium wilt, potato scab, and soil microbial populations. Can. J. Plant Pathol. 21:81-92.

2. Conn, K. L., and Lazarovits, G. 2000. Soil factors influencing the efficacy of liquid swine manure added to soil to kill Verticillium dahliae. Can. J. Plant Pathol. 22:400-406.

3. Conn, K. L., Tenuta, M., and Lazarovits, G. 2003. Volatile fatty acids in liquid swine manure are toxic to Verticillium dahliae in low $\mathrm{pH}$ soils. (Abstr.) Proc. Eighth Int. Congr. Plant Pathol. 2:273.

4. Cooper, P., and Cornforth, I. S. 1998. Volatile fatty acids in stored animal slurry. J. Sci. Food Agric. 29:19-27.

5. Freese, E., Sheu, C. W., and Galliers, E. 1973. Function of lipophilic acids as antimicrobial food additives. Nature 241:321-325.

6. Goepfert, J. M., and Hicks, R. 1969. Effect of volatile fatty acids on Salmonella typhimurium. J. Bacteriol. 97:956-958.

7. Hawke, M. A., and Lazarovits, G. 1994. Production and manipulation of individual microsclerotia of Verticillium dahliae for use in studies of survival. Phytopathology 84:883-890.

8. Lazarovits, G., Conn, K. L., Abbasi, P. A., and Tenuta, M. 2003. Control of soilborne plant pathogens with organic amendments: Challenges and possibilities. (Abstr.) Proc. Eight Int. Congr. Plant Pathol. 1:51.

9. Paul, J. W., and Beauchamp, E. G. 1989. Relationship between volatile fatty acids, total ammonia, and $\mathrm{pH}$ in manure slurries. Biol. Wastes 29:313-318.

10. Schwarzenbach, R., Gschwend, P., and Imboden, D. 2002. Environmental Organic Chemistry. 2nd ed. Wiley-Interscience, New York.

11. Sheldrick, B. H., and Wang, C. 1993. Particle size distribution. Pages 499511 in: Soil Sampling and Methods of Analysis. M. R. Carter, ed. Lewis Publishers, Boca Raton, FL.

12. Tenuta, M., Conn, K. L., and Lazarovits, G. 2002. Volatile fatty acids in liquid swine manure can kill microsclerotia of Verticillium dahliae. Phytopathology 92:548-552.

13. Tenuta, M., and Lazarovits, G. 2002. Ammonia and nitrous acid from nitrogenous amendments kill microsclerotia of Verticillium dahliae. Phytopathology 92:255-264.

14. Tenuta, M., and Lazarovits, G. 2002. Identification of specific soil properties that affect the accumulation and toxicity of ammonia to Verticillium dahliae. Can. J. Plant Pathol. 24:219-229.

15. Tenuta, M., and Lazarovits, G. 2004. Soil properties associated with the variable effectiveness of meat and bone meal to kill microsclerotia of Verticillium dahliae. Appl. Soil Ecol. 25:219-236.

16. Tiessen, H., and Moir, J. O. 1993. Total and organic carbon. Pages 187199 in: Soil Sampling and Methods of Analysis. M. R. Carter, ed. Lewis Publishers, Boca Raton, FL.

17. Tsao, P. H., and Oster, J. J. 1981. Relation of ammonia and nitrous acid to suppression of Phytophthora in nitrogenous organic substances. Phytopathology 71:53-59.

18. Wallace, R. J., Falconer, M. L., and Bhargava, P. K. 1989. Toxicity of volatile fatty acids at rumen $\mathrm{pH}$ prevents enrichment of Escherichia coli by sorbitol in rumen contents. Curr. Microbiol. 19:277-281. 